\title{
Study on the Frontiers of Assistive Technologies for Smart Learning in Learning Impairment of Dyslexic Children
}

\author{
J. Loveline Zeema \\ Research Scholar, School of Computer Studies \\ Rathinavel Subramaniam College of Arts and \\ Science \\ Sulur, Coimbatore, Tamilnadu, India
}

\author{
D. Fransis Xavier Christopher, PhD \\ Director, School of Computer Studies \\ Rathinavel Subramaniam College of Arts and \\ Science \\ Sulur, Coimbatore, Tamilnadu, India
}

\begin{abstract}
Learners with dyslexia are intuitive and perceive multidimensionality. But they face severe difficulty in reading, writing, mathematics and working memory. It is a different brain organization that needs different teaching methods. This article presents a methodical review of assistive technologies used for smart learning process with dyslexia. Type of technologies used in the assistive process is analyzed and listed. These include text-to-speech, Multimedia software, Touch sensation based learning, Multisensory, Games and Virtual learning Environment. The Text-to-Speech technology is the most common type of technology used by dyslexic learners. Most of the studies focus on dyslexic children. This review also finds that a majority of these studies focus on the use of multimedia and multisensory technologies for improving the reading ability of dyslexic learners.
\end{abstract}

\section{Keywords}

Dyslexia; Learning Impairment; Multisensory; Text-toSpeech, Speech-to-Text; Virtual Learning Environment

\section{INTRODUCTION}

Many children with learning disabilities have difficulties in particular skill areas, such as reading, writing or math. It is stated that more than one billion people in the world have some forms of learning disabilities and about 150 million of them are school-aged students (Laabidi et al., 2014). Dyslexia is most common in Learning Disabilities.

According to the Dyslexia Association of India dyslexia is defined as a neurological condition that affects the ability of a child to read, write and spell. British Dyslexia Association gives a statistic on dyslexia that it affects an estimated $10 \%$ of the population and approximately four percent of the world population is affected by severe dyslexia and another six percent have mild to moderate dyslexia.

Some possible indications of dyslexia in primary age children are confusion in left and right, difficulty in saying long words, subtracting, learning tables, saying months of the year, recalling digits, confuses $\mathrm{b}$ and $\mathrm{d}$ for longer than most children and family history of similar difficulties. Main difficulties of dyslexic children in learning are reading, writing, mathematical ability and memory. Assistive technology can be anything like a device or software that makes it easier to complete an everyday task. The use of assistive technology helps dyslexic learners to complete their tasks independently and efficiently. There are also several recent existing reviews of the literature on this development. This review focuses on the current development of how the assisting technology improves the learning of dyslexic children.

The rest of the paper is organized as follows: Section 2 outlines assistive technology. Next, types of commonly used assistive technologies are explored in section 3. Section 4 summarizes the contribution of assisted technologies in major domains of dyslexic learning from the selected articles. Findings in the review are described in Section 5. And Section 6 concludes this paper.

\section{ASSISTIVE TECHNOLOGY}

Assistive technology (AT) can be an equipment, software system or learning material which is used to increase, maintain, or improve the functional capabilities of persons with disabilities. The use of assistive technology is to assist people who have difficulty indifferent disabilities. In learning impairment of dyslexic children AT helps to complete their academic tasks efficiently. Different disabilities require different assistive technologies.

\section{TYPES OF ASSISTIVE TECHNOLOGIES}

The section shows that a lot of assistive technologies are available to support dyslexic learners. Most of the selected papers concentrate on the following types of technologies to improve the learning process of dyslexic learners, mainly textto-speech, multimedia, games, eye tracking, virtual learning environments and multisensory.

\subsection{Text-to Speech Technologies}

Most commonly used assistive technology by dyslexic learners is Text-to-speech technology. Alissa N.Antie et. al (2015), provides a tangible user interface PhonoBlocks [2] to a reading system. This system provides additional decoding information and modalities by Dynamic colored cues that are embedded in 3D tangible letters.

Schiavo \& Buson (2014) discussed the opportunities of using interactive e-Books [21] for improving the reading skills of dyslexic learners. Interactive e-Books allow the readers to record their voice while reading. In addition, the interactive eBooks permit the reader to listen and practice the recognition of basic units of speech within different words that aims to improve the reader's phonemic awareness as well as his or her ability to memorize and practice word recognition.

Rello et al. (2012) have given IDEAL eBook Reader [19] that displays eBooks in an easily understandable method based on reader's requirements. IDEAL eBook Reader permits the reader to customize the parameters (font designs, color, font 
size, brightness distinction, and spacing) for additional comfort while reading. It additionally provides DysWebxia default setting that sets all the parameters specified for dyslexic learners. And IDEAL eBook Reader supports text-tospeech technology that enables readers to concentrate on the eBook content within audio. This tool is compatible with textto-speech engines that support multiple languages. Additionally, the text is scanned for reading is highlighted so readers can easily follow the reading.

Rekha et al. (2013) developed Read-Aid [16], is an assistive reading tool to improve reading pattern among children with dyslexia. The Read-Aid Tool consists of two simple tabs: a start tab for setting the view (font settings and the number of words to display), and a read tab to read the targeted text. The intervention of Read-Aid Tool shows children's improvement in terms of reading speed, comprehension scores, and reduction in reading errors.

\subsection{Eye-Tracking Technologies}

Reading problems and phonological difficulties can be identified by experts through eye tracking technology. And particularly they designed effective remedial programs for dyslexic learners. Eye-tracking technology (ET) is an indirect way to improve the learning process of learners with dyslexia. Al-Edaily, et al.,(2013) provides Dyslexia Explorer [1], a screening system for dyslexia using an eye hold tracking technology. It is designed to help experts in analyzing the visual patterns of reading and aggregating the measures of eye gaze intensity and patterns. Dyslexia Explorer captures the eye movement when the learner is reading some scripts. Then, a Fixation Filtering Algorithm is used by the system to filter the gaze readings to fixation in a quick, simultaneous movement of both eyes in the same direction. Finally, the system analyzes the duration of fixations and spatial distribution.

\subsection{Virtual Learning Environment}

James Ohene-Djan et ai.,(2008) provides a virtual learning environment as a software system [7] designed to support teaching and learning. The study shows that the increased use of virtual learning environments for dyslexic learners, it was found that such virtual learning environments (VLE) improved their writing skills and writing activities. And, the word processor used in the virtual learning environment increases writing efficiency by providing spellchecker and grammar checker that highlight mistakes.

\subsection{Touch Sensation Technologies}

In this study Manoranjitham. M et al.,(2011) developed a computer based application incorporating touch sensation [11] to improve the entire learning experience of dyslexic children. Touch sensation in terms of kinesthetic or tactile based learning improves greatly the mental perception of dyslexic children. A prototype was developed incorporating a device Phantom Omni. In this application, three games were invented. In the first game, the children are asked to use the Phantom Omni Device to flip and turn around the alphabets to recognize them. In the second game, the children are allowed to write on top of the given alphabet using the Phantom Omni device. In the third game, the children are asked to pick up the colored sticks and drop them into the colored boxes provided. They have to use the Phantom Omni device for both pickup and drop-off process. The idea of associating touch sensation with dyslexic children opens the door for the better learning environment.

\subsection{Multisensory Technologies}

A multisensory technology consists of a string of multisensory (MS) learning strategies [12] including linking eyes, ears, voice, and hand movements of the children. Muhammad Haziq et al.,(2015) developed this "learn-to-read" application for the use of therapist/teacher. This learning media is designed to improve short-term memory. Children should remember numbers of objects for a specific time. Then, an object is taken from the list and the children should guess which one is missed. In this children should be able to identify the difference between the objects and maximize their visual memory ability. For reading, the dyslexic children are drilled to write an alphabet start from "a" to " $z$ ". And they can write with their hand if the computer is supported touch screen (tactile). Another media called "Plant your flowers" focus the children to use nearly all of their sensory receptors by listening to the sound (auditory), visualizing the syllables in the pot (visual) and picking the flowers by using their hand (kinesthetic and tactile if touch screen). Fig: 1 explains the types of assistive technologies used in these articles.



Fig1: Types of Assistive technologies used in this reviewed articles

Most commonly used assistive technology is Text-to-Speech.

\section{ROLE OF ASSISTIVE TECHNOLOGIES IN MAIN DOMAINS OF DYSLEXIC LEARNING}

This section discusses the four main areas that turn around the roles of the assistive technologies, which include providing aid for reading, writing, memory, and mathematical learning.

\subsection{Memory}

Virtual Reality (VR) technology offers safe and controlled environments. This provides a tremendous level of interactivity, immediate feedback. And this technology contributes to the improvement of visual processing skills (Phipps et al., 2002). Kalyvioti \& Mikropoulos (2012) developed in virtual reality environments to improve the memory performance of adults with dyslexia. Three memory systems (short-term memory, working memory, and long-term memory) were examined in the study. The study reveals that both dyslexic learners and non dyslexic learners showed similar memory performance with the aid of the virtual reality learning environments. 


\subsection{Reading}

Most of the papers in this study indicate that the use of assistive technologies to improve reading among learners with dyslexia. It is noticeable that reading can be improved either directly or indirectly. The most commonly used assistive technology to improve reading directly is the text-to-speech technology. Text-to-speech technology enables learners with dyslexia to listen and practice repetitively on the targeted words or texts. Thus, it can improve their word pronunciation, reading speed and decrease reading errors. Apart from that text-to-speech technologies can improve the phonological awareness, phonemic awareness and reduce the problem of phonemes omission. The assistive technology used in improving reading skills indirectly is the eye tracking technology. The eye tracker is used to capture the eye movement during the reading session of learners with dyslexia. The collected data are analyzed and the duration of fixations is determined. Conclusively, the eye tracking technologies allow experts to figure out the different patterns of reading problems among dyslexic learners and find a suitable solution for each category of patterns. Fig: 2 explain the role of assistive technologies in dyslexic learning.



Fig 2: Roll of Assistive Technologies in Dyslexic Learning.

In this study, 18 articles out of 22 are designed to improve reading among dyslexic learners.

\subsection{Writing}

As exposed in this review, writing is another important purpose for the use of assistive technologies. The technologies used in improving the writing skills of dyslexic learners include voice recognition software, computer games virtual learning environments. While text-to-speech technologies translate written text to spoken speech, the voice recognition software translates speech to text on the screen for dyslexic learners. It improves their spelling and writing.

\subsection{Mathematical Ability}

Dyslexic learners face problems in seeing words, writing numbers in the inverted form, and solving arithmetic calculations. There are two studies [6] and [23] that discussed the assistive technologies used in improving the mathematical skills of dyslexic learners. Siti Zulaiha Ahmad et al.,(2013) provides MathLexic[23], an interactive multimedia application to improve the mathematical learning among learners with dyslexia. It provides exercises to improve the performance of children with dyslexia in various aspects such as number recognition, number sequence, mathematical symbols and mathematical operations. Fig: 3 explain the type of proposed assistive technology in the reviewed articles.

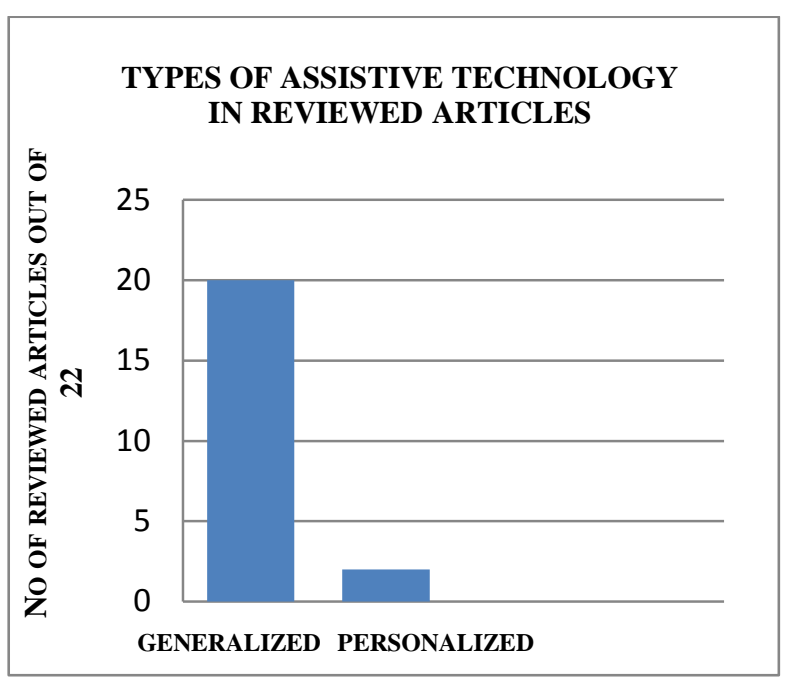

Fig 3: Types of proposed assistive Technologies in reviewed articles.

In this study, 20 articles out of 22 suggest a generalized way of learning in dyslexic learners.

\section{FINDINGS IN THE ARTICLE}

It was found that the majority of the study focused on children. The review also reveals that existing assistive technologies functions to improve the learning process of dyslexic learners, particularly their reading and writing as well as improving their memory and mathematical skills. Table: 1 to Table: 4 summarize the analysis of technologies used for dyslexic learning.

\section{CONCLUSION}

This study provides a synthesized view of the current state of assistive technologies used in improving the learning process of dyslexic learners. According to the review, it is clearly understood that dyslexic children need extra support to develop reading, writing, mathematical skills or working memory. Most of the studies focus on the general learning process. But a personalized learning environment based on cognitive inclinations of dyslexic learners will produce better learning experience. The learning of dyslexic children will be improved when the learning environment adapt a personalized assistive technology based on the cognitive traits of the individual dyslexic learner. 
Table1: Analysis of technologies used for dyslexic learning in Reviewed Papers

\begin{tabular}{|c|c|c|c|c|c|c|c|}
\hline & Article & $\begin{array}{c}\text { Target } \\
\text { Participants }\end{array}$ & $\begin{array}{l}\text { Participa } \\
\text { nt age }\end{array}$ & $\begin{array}{l}\text { Personalized } \\
\text { / General }\end{array}$ & $\begin{array}{c}\text { Assistive } \\
\text { Technology } \\
\text { Used }\end{array}$ & $\begin{array}{c}\text { Type of } \\
\text { Technology } \\
\text { Used }\end{array}$ & Purpose \\
\hline$[1]$ & $\begin{array}{l}\text { Dyslexia Explorer: A } \\
\text { Screening System for } \\
\text { : Learning Difficulties in } \\
\text { the Arabic Language } \\
\text { Using Eye Tracking }\end{array}$ & $\begin{array}{c}\text { Readers with } \\
\text { and without } \\
\text { dyslexia } \\
14 \text { children(7 } \\
\text { with dyslexia, } 7 \\
\text { without } \\
\text { dyslexia) }\end{array}$ & $\begin{array}{l}10-12 \\
\text { years }\end{array}$ & General & $\begin{array}{l}\text { Dyslexia } \\
\text { Explorer } \\
\text { Screening } \\
\text { system }\end{array}$ & Eye tracking & $\begin{array}{l}\text { Screening readers with } \\
\text { eye tracker for dyslexia }\end{array}$ \\
\hline$[2]$ & $\begin{array}{l}\text { PhonoBlocks: A Tangible } \\
\text { System for Supporting } \\
\text { Dyslexic Children } \\
\text { Learning to Read }\end{array}$ & $\begin{array}{l}\text { Dyslexic } \\
\text { Children }\end{array}$ & $5-8$ year & General & $\begin{array}{l}\text { Tangible User } \\
\text { interface (3D } \\
\text { letters) }\end{array}$ & $\begin{array}{l}\text { Tangible } \\
\text { letters with } \\
\text { tactile } \\
\text { qualities }\end{array}$ & $\begin{array}{l}\text { To learn decoding of } \\
\text { English letter-sound pairs }\end{array}$ \\
\hline$[3]$ & $\begin{array}{l}\text { MyLexic: An Assistive } \\
\text { Multimedia Courseware } \\
\text { for Teaching and } \\
\text { Reinforcing Basic } \\
\text { Reading Skills among } \\
\text { Dyslexics }\end{array}$ & $\begin{array}{l}\text { Primary School } \\
\text { Dyslexic } \\
\text { children in } \\
\text { Malaysia }\end{array}$ & & General & $\begin{array}{l}\text { Multimedia } \\
\text { Courseware } \\
\text { (MyLexic) }\end{array}$ & $\begin{array}{l}\text { Multimedia } \\
\text { Approach } \\
\text { Dual coding } \\
\text { theory, } \\
\text { Scaffolding } \\
\text { teaching } \\
\text { strategy }\end{array}$ & $\begin{array}{l}\text { To learn and recognize } \\
\text { alphabets, make a } \\
\text { syllable and read a simple } \\
\text { word }\end{array}$ \\
\hline$[4]$ & $\begin{array}{l}\text { Personalized assessment } \\
\text { model for alphabets } \\
: \text { learning with learning } \\
\text { objects in e-learning } \\
\text { environment for dyslexia }\end{array}$ & $\begin{array}{l}\text { Elementary } \\
\text { school dyslexic } \\
\text { children }\end{array}$ & $6-9$ years & Personalized & $\begin{array}{l}\text { Personalized e- } \\
\text { learning model }\end{array}$ & $\begin{array}{l}\text { Preparing } \\
\text { knowledge } \\
\text { base, } \\
\text { Learning } \\
\text { Models }\end{array}$ & $\begin{array}{l}\text { Each dyslexic student } \\
\text { gets learning content } \\
\text { based on their cognitive } \\
\text { traits }\end{array}$ \\
\hline
\end{tabular}

Table2: Analysis of technologies used for dyslexic learning in Reviewed Papers(Contd..)

\begin{tabular}{|c|c|c|c|c|c|c|c|c|}
\hline & & Article & $\begin{array}{c}\text { Target } \\
\text { Participants }\end{array}$ & $\begin{array}{l}\text { Participa } \\
\text { nt age }\end{array}$ & $\begin{array}{l}\text { Personalized } \\
\text { / General }\end{array}$ & $\begin{array}{l}\text { Assistive } \\
\text { Technology } \\
\text { Used }\end{array}$ & $\begin{array}{l}\text { Type of } \\
\text { Technology } \\
\text { Used }\end{array}$ & Purpose \\
\hline$[5]$ & : & $\begin{array}{l}\text { Integration of a } \\
\text { framework with a } \\
\text { learning management } \\
\text { system for detection, } \\
\text { assessment and } \\
\text { assistance of university } \\
\text { students with reading } \\
\text { difficulties }\end{array}$ & $\begin{array}{l}\text { Spanish } \\
\text { speaking } \\
\text { University } \\
\text { Students(dyslexi } \\
\text { c and not } \\
\text { dyslexic) }\end{array}$ & & General & $\begin{array}{l}\text { Web based } \\
\text { Learning } \\
\text { Management } \\
\text { system } \\
\text { LMS(interface } \\
\text { with Moodle) }\end{array}$ & $\begin{array}{l}\text { Multisensory } \\
\text { technique }\end{array}$ & $\begin{array}{l}\text { Providing an integrated } \\
\text { tool with Moodle for } \\
\text { improved learning access } \\
\text { of Spanish speaking } \\
\text { dyslexic university } \\
\text { students, assisting tool } \\
\text { for teachers }\end{array}$ \\
\hline [6] & : & $\begin{array}{l}\text { Multisensory Games for } \\
\text { Dyslexic Children }\end{array}$ & $\begin{array}{l}\text { Dyslexic } \\
\text { Children }\end{array}$ & & General & Game(DAS) & $\begin{array}{l}\text { Multisensory } \\
\text { technique }\end{array}$ & $\begin{array}{l}\text { To identify mistakes in } \\
\text { reading, writing and } \\
\text { arithmetic }\end{array}$ \\
\hline [7] & : & $\begin{array}{l}\text { Dyslexic students in } \\
\text { higher education and } \\
\text { virtual learning } \\
\text { environments: an } \\
\text { exploratory study }\end{array}$ & $\begin{array}{l}12 \text { adults with } \\
\text { dyslexia- in } \\
\text { semi structured } \\
\text { interviews, } 24 \\
\text { adults ( } 12 \text { with } \\
\text { dyslexia and } 12 \\
\text { without } \\
\text { dyslexia)-in } \\
\text { questionnaire } \\
\text { survey }\end{array}$ & $\begin{array}{l}19 \text { to } 36 \\
\text { years }\end{array}$ & General & $\begin{array}{l}\text { Virtual } \\
\text { learning } \\
\text { environments } \\
\text { (VLEs) } \\
\text {-VLE Fronter } \\
\text {-eye-tracking } \\
\text { device } \\
\text {-talking word } \\
\text { processer }\end{array}$ & $\begin{array}{l}\text { Qualitative } \\
\text { data } \\
\text {-semi } \\
\text { structured } \\
\text { interviews } \\
\text { Quantitative } \\
\text { data } \\
\text { - } \\
\text { questionnaire }\end{array}$ & $\begin{array}{l}\text { To provide better } \\
\text { writing, } \\
\text { time saving } \\
\text { (spellchecker and } \\
\text { grammar checker } \\
\text { highlight mistakes), } \\
\text { identify and correct } \\
\text { errors }\end{array}$ \\
\hline [8] & & $\begin{array}{l}\text { Memory performance of } \\
\text { dyslexic adults in virtual } \\
\text { environments. }\end{array}$ & $\begin{array}{l}\text { Control group: } 7 \\
\text { students without } \\
\text { dyslexia ( } 3 \text { male } \\
\text { and } 4 \text { female) } \\
\text { Experimental } \\
\text { group: } 7 \\
\text { students with } \\
\text { dyslexia ( } 4 \text { male } \\
\text { and } 3 \text { female) }\end{array}$ & $\begin{array}{l}\text { Undergrad } \\
\text { uate } \\
\text { students of } \\
\text { University } \\
\text { of } \\
\text { Ioannina, } \\
\text { Greece }\end{array}$ & General & $\begin{array}{l}\text { VIRDA-MS } \\
\text { (Virtual } \\
\text { Reality } \\
\text { Dyslexia } \\
\text { Assessment- } \\
\text { Memory } \\
\text { Screening) }\end{array}$ & $\begin{array}{l}\text { Virtual } \\
\text { Reality }\end{array}$ & $\begin{array}{l}\text { To help to manage daily } \\
\text { memory challenges, } \\
\text { tackling short term } \\
\text { memory and long-term } \\
\text { memory }\end{array}$ \\
\hline
\end{tabular}


Table3: Analysis of technologies used for dyslexic learning in Reviewed Papers (Contd...)

\begin{tabular}{|c|c|c|c|c|c|c|c|c|}
\hline & & Article & $\begin{array}{c}\text { Target } \\
\text { Participants }\end{array}$ & $\begin{array}{c}\text { Participa } \\
\text { nt age }\end{array}$ & $\begin{array}{l}\text { Personalized } \\
\text { / General }\end{array}$ & $\begin{array}{c}\text { Assistive } \\
\text { Technology } \\
\text { Used } \\
\end{array}$ & $\begin{array}{c}\text { Type of } \\
\text { Technology } \\
\text { Used }\end{array}$ & Purpose \\
\hline$[10]$ & : & $\begin{array}{l}\text { Phonological Awareness } \\
\text { Software for Dyslexic } \\
\text { Children }\end{array}$ & $\begin{array}{l}\text { Dyslexic } \\
\text { children }\end{array}$ & $\begin{array}{l}\text { Different } \\
\text { age groups }\end{array}$ & General & $\begin{array}{l}\text { PHASE } \\
\text { multimedia } \\
\text { Application }\end{array}$ & $\begin{array}{l}\text { Multisensory } \\
\text { Approach, } \\
\text { Computer } \\
\text { based } \\
\text { intervention } \\
\text { programs }\end{array}$ & $\begin{array}{l}\text { To assist teaching efforts } \\
\text { for phonemes in } \\
\text { dyslexic children }\end{array}$ \\
\hline [11] & : & $\begin{array}{l}\text { Touch Sensation Based } \\
\text { Computer Application to } \\
\text { Facilitate the Learning } \\
\text { Process of Dyslexic } \\
\text { Children }\end{array}$ & $\begin{array}{l}\text { Children of } \\
\text { Dyslexia } \\
\text { Awareness } \\
\text { Malaysia(DAM) }\end{array}$ & $3-8$ years & General & $\begin{array}{l}\text { Touch } \\
\text { sensation } \\
\text { ((Phantom } \\
\text { Omni) based } \\
\text { Application }\end{array}$ & $\begin{array}{l}\text { Touch } \\
\text { sensation } \\
\text { along with } \\
\text { color, } \\
\text { graphics, } \\
\text { text, sound } \\
\text { and } \\
\text { animation }\end{array}$ & $\begin{array}{l}\text { To improve motor skills } \\
\text { of dyslexics along with } \\
\text { multisensory skills }\end{array}$ \\
\hline$[12]$ & : & $\begin{array}{l}\text { "Learn-to-read" } \\
\text { Application for } \\
\text { Remediation of Dyslexic } \\
\text { Children Based on } \\
\text { Multisensory Approach }\end{array}$ & $\begin{array}{l}\text { Indonesian } \\
\text { Dyslexic } \\
\text { children and } \\
\text { Dyslexic } \\
\text { therapist }\end{array}$ & $5-7$ year & General & $\begin{array}{l}\text { Multisensory } \\
\text { game App in } \\
\text { Indonesian } \\
\text { language }\end{array}$ & $\begin{array}{l}\text { Agile } \\
\text { methodology, } \\
\text { Multisensory } \\
\text { Approach }\end{array}$ & $\begin{array}{l}\text { To assist dyslexic } \\
\text { therapist, utilizing all } \\
\text { sensory receptors of } \\
\text { dyslexic }\end{array}$ \\
\hline [13] & : & $\begin{array}{l}\text { MyLexics: An Assistive } \\
\text { Courseware for Dyslexic } \\
\text { Children to Learn Basic } \\
\text { Malay Language }\end{array}$ & $\begin{array}{l}\text { Children those } \\
\text { having learning } \\
\text { difficulties such } \\
\text { as dyslexia, } \\
\text { autism, ADHD } \\
\text { and slow } \\
\text { learner. }\end{array}$ & & General & Courseware & $\begin{array}{l}\text { Multimedia } \\
\text { Approach }\end{array}$ & $\begin{array}{l}\text { recognizing and writing } \\
\text { alphabet, individual } \\
\text { vowel and consonant and } \\
\text { its sound, read simple } \\
\text { words }\end{array}$ \\
\hline
\end{tabular}

Table 4: Analysis of technologies used for dyslexic learning in Reviewed Papers (Contd...)

\begin{tabular}{|c|c|c|c|c|c|c|c|c|}
\hline & & Article & $\begin{array}{c}\text { Target } \\
\text { Participants }\end{array}$ & $\begin{array}{c}\text { Participa } \\
\text { nt age }\end{array}$ & $\begin{array}{c}\text { Personalized } \\
\text { / General }\end{array}$ & $\begin{array}{c}\text { Assistive } \\
\text { Technology } \\
\text { Used } \\
\end{array}$ & $\begin{array}{c}\text { Type of } \\
\text { Technology } \\
\text { Used }\end{array}$ & Purpose \\
\hline [14] & : & $\begin{array}{l}\text { Adaptive Reading } \\
\text { Assistance for the } \\
\text { Inclusion of Learners } \\
\text { with Dyslexia: The } \\
\text { AGENT-DYSL } \\
\text { approach }\end{array}$ & $\begin{array}{l}\text { Dyslexic } \\
\text { learners }\end{array}$ & $\begin{array}{l}\text { Different } \\
\text { age }\end{array}$ & Personalized & $\begin{array}{l}\text { AGENT- } \\
\text { DYSL } \\
\text { (supporting } \\
\text { Software) }\end{array}$ & $\begin{array}{l}\text { Speech } \\
\text { recognition, } \\
\text { image } \\
\text { recognition, } \\
\text { error type } \\
\text { profiling for } \\
\text { personalized } \\
\text { support }\end{array}$ & $\begin{array}{l}\text { Personalized support for } \\
\text { learner, Providing age } \\
\text { appropriate and dyslexia } \\
\text { sensitive user interface } \\
\text { developing reading skills } \\
\text { by adjusting and adapting } \\
\text { environmental needs. }\end{array}$ \\
\hline [16] & : & $\begin{array}{l}\text { Read-Aid-An Assistive } \\
\text { Reading Tool for } \\
\text { Children with Dyslexia }\end{array}$ & $\begin{array}{l}15 \text { children }(12 \\
\text { dyslexics, } 3 \text { not } \\
\text { dyslexics })\end{array}$ & $\begin{array}{l}8.5-11.5 \\
\text { years }\end{array}$ & General & Read-Aid Tool & $\begin{array}{l}\text { QT GUI } \\
\text { front-end, } \\
\text { C++ } \\
\text { backend, } \\
\text { Masked-text } \\
\text { technique } \\
\end{array}$ & $\begin{array}{l}\text { To improve reading } \\
\text { pattern of dyslexic } \\
\text { children }\end{array}$ \\
\hline$[17]$ & : & $\begin{array}{l}\text { Evaluation of } \\
\text { Dyswebxia: A reading } \\
\text { app designed for people } \\
\text { with dyslexia }\end{array}$ & $\begin{array}{l}\text { Experimental } \\
\text { group: } 32 \\
\text { participants with } \\
\text { dyslexia ( } 18 \\
\text { female and } 14 \\
\text { male) } \\
\text { Control group: } \\
38 \text { participants } \\
\text { without dyslexia } \\
\text { ( } 24 \text { female and } \\
14 \text { male) } \\
\text { Usability } \\
\text { evaluation: } 12 \\
\text { participants with } \\
\text { dyslexia (3 } \\
\text { female and } 9 \\
\text { male) }\end{array}$ & & General & $\begin{array}{l}\text { DysWebxia } \\
\text { CASSA } \\
\text { (Context } \\
\text { Aware } \\
\text { Synonym } \\
\text { Simplification } \\
\text { Algorithms) }\end{array}$ & $\begin{array}{l}\text {-online } \\
\text { questionnaire } \\
\text {-semi- } \\
\text { structured } \\
\text { interview }\end{array}$ & $\begin{array}{l}\text { To improve reading } \\
\text { performance, to provide } \\
\text { suitable and simpler } \\
\text { synonyms for complex } \\
\text { words }\end{array}$ \\
\hline
\end{tabular}


Table 5: Analysis of technologies used for dyslexic learning in Reviewed Papers (Contd...)

\begin{tabular}{|c|c|c|c|c|c|c|c|}
\hline & Article & $\begin{array}{c}\text { Target } \\
\text { Participants }\end{array}$ & $\begin{array}{l}\text { Participa } \\
\text { nt age }\end{array}$ & $\begin{array}{l}\text { Personalized } \\
\text { / General }\end{array}$ & $\begin{array}{c}\text { Assistive } \\
\text { Technology } \\
\text { Used } \\
\end{array}$ & $\begin{array}{c}\text { Type of } \\
\text { Technology } \\
\text { Used }\end{array}$ & Purpose \\
\hline [18] & $\begin{array}{l}\text { A Computer based } \\
\text { method to improve the } \\
\text { spelling of children with } \\
\text { dyslexia }\end{array}$ & $\begin{array}{l}48(29 \text { girls, } 19 \\
\text { boys }) \text { dyslexic } \\
\text { children }\end{array}$ & & General & $\begin{array}{l}\text { Game for iPad } \\
\text { DysEggxia }\end{array}$ & $\begin{array}{l}\text { Onscreen text } \\
\text { readability }\end{array}$ & $\begin{array}{l}\text { Improving the spelling } \\
\text { and reading of dyslexic } \\
\text { children }\end{array}$ \\
\hline [19] & $\begin{array}{l}\text { A mobile application for } \\
\text { displaying more } \\
\text { accessible eBooks for } \\
\text { people with Dyslexia }\end{array}$ & $\begin{array}{l}54 \text { with learning } \\
\text { difficulties } \\
48 \text { children with } \\
\text { dyslexia ( } 29 \\
\text { girls and } 19 \\
\text { boys) }\end{array}$ & $\begin{array}{l}6 \text { to } 11 \\
\text { years }\end{array}$ & General & $\begin{array}{l}\text { DysEggxia } \\
\text { (game } \\
\text { designed to } \\
\text { support } \\
\text { spelling } \\
\text { acquisition) }\end{array}$ & $\begin{array}{l}\text { Text-to- } \\
\text { speech }\end{array}$ & $\begin{array}{l}\text { To provide better } \\
\text { writing, improve spelling } \\
\text { skills, } \\
\text { reduce spelling errors }\end{array}$ \\
\hline [20] & $\begin{array}{l}\text { "Dyslexia Baca" Mobile } \\
\text { App-The Learning } \\
\text { Ecosystem for Dyslexic } \\
\text { Children }\end{array}$ & $\begin{array}{l}\text { Dyslexic } \\
\text { Children }\end{array}$ & $\begin{array}{l}114 \\
\text { children of } \\
\text { age } 4-7 \\
\text { years }\end{array}$ & General & $\begin{array}{l}\text { Developmental } \\
\text { research } \\
\text { (Mobile App } \\
\text { in Malay } \\
\text { Language) }\end{array}$ & $\begin{array}{l}\text { Multimedia } \\
\text { Approach }\end{array}$ & $\begin{array}{l}\text { recognizing alphabet, } \\
\text { memorizing alphabet } \\
\text { name, recalling the } \\
\text { information }\end{array}$ \\
\hline
\end{tabular}

Table 6: Analysis of technologies used for dyslexic learning in Reviewed Papers

\begin{tabular}{|c|c|c|c|c|c|c|c|c|}
\hline & & Article & $\begin{array}{c}\text { Target } \\
\text { Participants }\end{array}$ & $\begin{array}{l}\text { Participa } \\
\text { nt age }\end{array}$ & $\begin{array}{l}\text { Personalized } \\
\text { / General }\end{array}$ & $\begin{array}{l}\text { Assistive } \\
\text { Technology } \\
\text { Used }\end{array}$ & $\begin{array}{l}\text { Type of } \\
\text { Technology } \\
\text { Used }\end{array}$ & Purpose \\
\hline [21] & : & $\begin{array}{l}\text { Interactive e-Books to } \\
\text { support reading skills in } \\
\text { dyslexia }\end{array}$ & $\begin{array}{l}\text { Dyslexic } \\
\text { Children }\end{array}$ & & General & $\begin{array}{l}\text { Interactive } \\
\text { eBooks }\end{array}$ & $\begin{array}{l}\text { Text to } \\
\text { Speech }\end{array}$ & $\begin{array}{l}\text { To provide better } \\
\text { Reading, } \\
\text { improve in memorizing, } \\
\text { practise word, } \\
\text { pronunciation, improve } \\
\text { phonemic awareness }\end{array}$ \\
\hline [22] & : & $\begin{array}{l}\text { Informing Design of an } \\
\text { Adaptive Learning } \\
\text { Model for student with } \\
\text { Dyslexia: A Preliminary } \\
\text { Study }\end{array}$ & $\begin{array}{l}\text { Dyslexic } \\
\text { Children }\end{array}$ & & General & $\begin{array}{l}\text { Adaptive } \\
\text { learning model }\end{array}$ & $\begin{array}{l}\text { Multisensory } \\
\text { Approach }\end{array}$ & $\begin{array}{l}\text { To focus on individual } \\
\text { need, personal } \\
\text { intervention based on } \\
\text { student's difficulties and } \\
\text { behaviour }\end{array}$ \\
\hline [23] & : & $\begin{array}{l}\text { MathLexic: An } \\
\text { Assistive Multimedia } \\
\text { Mathematical Learning } \\
\text { Aid for Dyslexia } \\
\text { Children }\end{array}$ & $\begin{array}{l}\text { Dyslexic } \\
\text { Children }\end{array}$ & & General & $\begin{array}{l}\text { Multimedia } \\
\text { mathematical } \\
\text { tool- } \\
\text { MathLexic }\end{array}$ & $\begin{array}{l}\text { Multimedia } \\
\text { Application }\end{array}$ & $\begin{array}{l}\text { To improve } \\
\text { mathematical skills of } \\
\text { dyslexic children, } \\
\text { recognizing numbers, } \\
\text { number sequence, } \\
\text { operation of } \\
\text { mathematical symbol }\end{array}$ \\
\hline
\end{tabular}

\section{REFERENCES}

[1] Al-Edaily, A., Al-Wabil, A., \& Al-Ohali, Y. (2013). Dyslexia Explorer: A Screening System for Learning Difficulties in the Arabic Language Using Eye Tracking. In Human Factors in Computing and Informatics (pp. 831-834). Springer, Berlin, Heidelberg.

[2] Alissa N.Antie, Min Fan, Emily S.Cramer "PhonoBlocks: A Tangible System for Supporting Dyslexic Children Learning to Read"(2015).ACM.

[3] Anusuriya Devaraju, Zeratul Izzah Mohd Yusoh, Mohd Hafiz Zakaria, Umawathy Techanamurthy, University Technical Malaysia Melaka, Malaysia(2007).MyLexic: An Assistive Multimedia
Courseware for Teaching and Reinforcing Basic Reading Skills among Dyslexics. AACE.

[4] Bhavana Srivastava, Md.Tanwir Uddin Haider. (2017). Personalized assessment model for alphabets learning with learning objects in an elearning environment for dyslexia. ELSEVIER.

[5] Carolina Mejía Corredor, Ramón Fábregatb Gesa, Daniel Salas Álvarez (2012) "Integration of a framework with a learning management system for detection, assessment, and assistance of university students with reading difficulties".IEEE.

[6] James Ohene-Djan and Rahima Begum (2008). Multisensory Games for Dyslexic Children.IEEE 
[7] Habib, L., Berget, G., Sandnes, F. E., Sanderson, N., Kahn, P., Fagernes, S., \& Olcay, A. (2012). Dyslexic students in higher education and virtual learning environments: an exploratory study. Journal of Computer Assisted Learning, 28(6), 574584

[8] Kalyvioti, K., \& Mikropoulos, T. A. (2012). Memory performance of dyslexic adults in virtual environments. Procedia Computer Science, 14, 410418. Laabidi, Mohsen, Jemni M., Leila J. B., Ayed, Brahim, H.B. \& Jemaa, A. B. (2014). Learning Technology for People with Disabilities. Journal of King Saud University - Computer and Information Sciences, 26, 2945

[9] Laabidi, Mohsen, Jemni M., Leila J. B., Ayed, Brahim, H.B. \& Jemaa, A. B. (2014). Learning Technology for People with Disabilities. Journal of King Saud University - Computer and Information Sciences, 26, 2945.

[10] Maria Kazakou, Spyros Soulis, Eleni Morfidi, Tasso s A. Mikropoulos. (2011). Phonological Awareness Software for Dyslexic Children. Themes in Science $\&$ Technology Education.

[11] Manoranjitham.M, Lim Kok Ooi, K.S Savita. (2011).Touch Sensation Based Computer Application to Facilitate the Learning Process of Dyslexic Children. American Scientific Publisher.

[12] Muhamad Risqi Utama Saputra and Kuntoro Adi Nugroho. (2015) "Learn-to-read" Application for Remediation of Dyslexic Children Based on Multisensory Approach. IOSR-JHSS

[13] Muhammad Haziq Lim Abdullah, Syariffanor Hisham, Shahril Parumo. MyLexics: An Assistive Courseware for Dyslexic Children to Learn Basic Malay Language.(2009).ACM.

[14] Paraskevi Tzouveli, Andreas Schmidt, Michael Schneider, Antonis Symvonis, Stefanos Kollias., S. (2008, July). Adaptive reading assistance for the inclusion of students with dyslexia: The AGENTDYSL approach. In Advanced Learning Technologies, 2008. ICALT'08. Eighth IEEE International Conference on (pp. 167-171). IEEE.

[15] Phipps, L., Sutherland, A., \& Seale, J. (2002). Access All Areas: disability, technology, and learning. TechDis with the Association for Learning Technology.

[16] Rekha, S., Gollapudi, S., Sampath, H., \& Indurkhya, B. (2013, July). ReadAid-an assistive reading tool for children with dyslexia. In International Conference on Universal Access in HumanComputer Interaction (pp. 297-304). Springer, Berlin, Heidelberg.

[17] Rello, L., \& Baeza-Yates, R. (2014, April). Evaluation of Dyswebxia: A reading app designed for people with dyslexia. In Proceedings of the 11th Web for All Conference (p. 10). ACM.

[18] Rello, L., Bayarri, C., Otal, Y., \& Pielot, M. (2014, October). A computer-based method to improve the spelling of children with dyslexia. In Proceedings of the 16th international ACM SIGACCESS conference on Computers \& accessibility (pp. 153160). ACM.

[19] Rello, L., Kanvinde, G., \& Baeza-Yates, R. (2012). A mobile application for displaying more accessible eBooks for people with Dyslexia. Procedia Computer Science, 14, 226-233.

[20] Salwani Mohd Daud and Hafiza Abas - "Dyslexia Baca" Mobile App - The Learning Ecosystem for Dyslexic Children(2013) international conference on advanced computer science applications and technologies

[21] Schiavo, G., \& Buson, V. (2014). Interactive eBooks to support reading skills in dyslexia. In at IBOOC2014-2nd Workshop on Interactive eBook for Children at IDC

[22] Siti Suhaila Abdul Hamid, Novia Admodisastro, Azrina Kamaruddin, Noridayu Manshor Abdul Azim Abdul Ghani (2017). Informing Design of an Adaptive Learning Model for a student with Dyslexia: A Preliminary Study.ACM.

[23] Siti Zulaiha Ahmad, Noor Izzati Jinon, Arifah Fasha Rosmani "MathLexic: An Assistive Multimedia Mathematical Learning Aid for Dyslexia Children". (2013) IEEE. 